\title{
STATISTIKA UNTUK PENGOLAHAN DATA HASIL PENELITIAN TINDAKAN KELAS (PTK) KELOMPOK MUSYAWARAH GURU MATA PELAJARAN (MGMP) DI SMP RAYON BANDUNG SELATAN
}

\author{
Sri Suratmi, Siti Samsiyah Purwaningsih, Euis Sartika, Anny Suryani \\ srisuratmi polban@yahoo.com,sitisamsivahpurwaningsih@yahoo.co.id, \\ euissartika sartika@yahoo.com, annysuryani@ymail.com \\ UP MKU Politeknik Negeri Bandung
}

\begin{abstract}
Salah satu Program Peningkatan Mutu Pendidik dan Tenaga Kependidikan pada guruguru SD, SMP,SMA, atau SMK adalah Pelaksanaan sertifikasi pendidik. Komponen penilaian para guru untuk mendapatkan sertifikasi guru, salah satunya adalah portofolio mengenai Penelitian Tindakan Kelas (PTK). Berdasarkan hasil penilaian, diperoleh hasil bahwa komponen karya pengembangan profesi melalui PTK para guru dinilai rendah, khususnya penelitian di bidang pendidikan yakni Penelitian Tindakan Kelas (PTK). Studi pendahuluan yang dilakukan melalui wawancara dengan Pembina MGMP Rayon Bandung Selatan diperoleh informasi bahwa kegitan pelatihan yang terkait Pelatihan analisis data Statistika untuk Penelitian Tindakan Kelas belum pernah dilakukan. Atas dasar inilah, team Pengabdian Masyarakat Polban memberi alternatif penyelesaian dengfan memberi bantuan dalam bentuk pelatihan "Statistika untuk Pengolahan Data Hasil Penelitian Tindakan Kelas (PTK)". Tujuan dari kegiatan pelatihan ini adalah . meningkatkan kemampuan para guru untuk aktif berperan mengevaluasi hasil pembelajaran yang dilakukannya evaluasi Penelitian Tindakan Kelas (PTK). Kegiatan ini diikuti oleh 20 peserta yang terdiri dari guru-guru SMP yang tergabung dalam MGMP Rayon Bandung Selatan yang mewakili SMP-SMP di wilayah tersebut selama kurang lebih 40 jam bertempat di SMP negeri 43 Bandung. Hasil analisis menunjukkan bahwa terdapat peningkatan kemampuan peserta dalam analisis Statistik untuk pengolahan data PTK secara signifikan sebesar 27,02\%.
\end{abstract}

\section{Keyword : Penelitian Tindakan Kelas (PTK), sertikasi Pendidik, Statistika}

\section{Pendahuluan}

Undang-undang Republik

Indonesia Nomor 14 Tahun 2005 tentang Guru dan Dosen, menyatakan bahwa Guru adalah pendidik profesional dengan tugas utama mendidik, mengajar dan membimbing, mengarahkan, melatih, menilai, dan mengevaluasi peserta didik pada usia dini jalur pendidikan sekolah formal, pendididikan dasar dan pendidikan menengah, dan poin 2 yang dimaksud dengan Dosen adalah pendidik profesional dan ilmuwan dengan tugas utama mentransformasikan, mengembangkan, dan memperluas ilmu pengetahuan, teknologi, dan seni melalui pendidikan, penelitian, dan pengabdian pada masyarakat. Jadi, pada hakekatnya Guru dan Dosen memiliki persamaan dalam menjalankan fungsi sehingga dapat berkolaborasi 
ketika dosen hendak melakukan pengabdian kepada masyarakat dan mengambil bagian dari masyarakat yakni kelompok guru menjadikan mitranya.

$\begin{array}{rcr}\text { Pada } & \text { saat } & \text { pelaksanaan } \\ \text { sertifikasi } & \text { bagi } & \text { guru-guru } \\ \text { SD } & \text { SMP }\end{array}$
SD,SMP,SMA, maupun SMK, portofolio adalah bukti fisik (dokumen) yang harus dikumpulkan dan selanjutnya dinilai oleh assesor untuk mengetahui lolos tidaknya seorang guru untuk mendapatkan sertifikat sebagai guru yang profesional. Pengalaman dari para assesor menemukan bahwa dari 10 komponen, ada salah satu komponen yang nilainya 0 (nol) karena dokumen tersebut tidak diisi yaitu komponen karya pengembangan profesi, khususnya karya penelitan di bidang pendidikan. Kondisi semacam ini terjadi baik pada guru-guru yang lolos sertifikasi maupun yang tidak lolos dan harus mengikuti PLPG. Hal ini menunjukkan bahwa kemampuan guruguru untuk melaksanakan penelitian di bidang pendidikan masih sangat kurang, termasuk dalam penelitian tindakan kelas . Dari para guru yang tidak lolos sertifikasi terungkap pula bahwa mereka sangat membutuhkan pelatihanpelatihan tentang penelitian tindakan kelas. Mereka menyadari bahwa penelitian ini sangat bermanfaat dan sangat dibutuhkan bagi seorang guru yang sudah profesional.

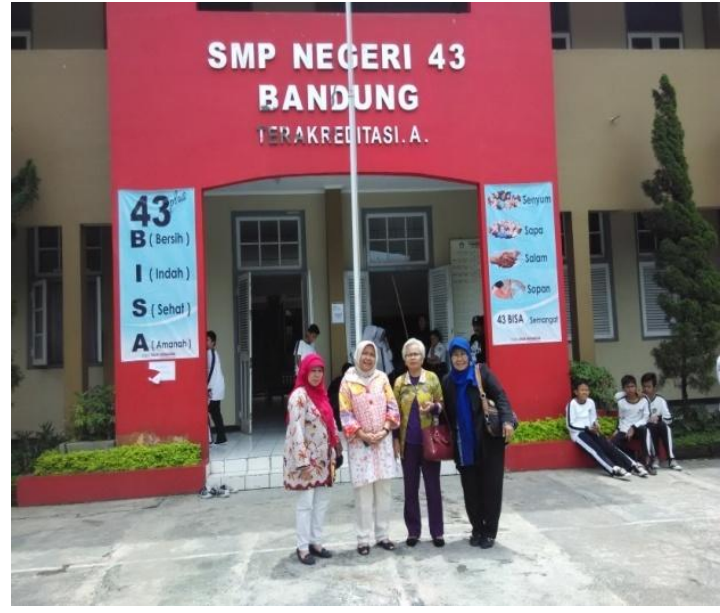

Gambar 1. Lokasi Kegiatan Pelatihan MGMP Rayon Bandung Selatan

\section{Menurut Pembina MGMP} Rayon Bandung Selatan disampaikan bahwa guru-guru SMP khususnya guru MGMP rayon Bandung Selatan memerlukan kemampuan pengolahan data untuk PTK, namun belum setiap guru memiliki kemampuan tersebut. Beliau juga menambahkan, keterbatasan jumlah guru dalam mengikuti kegiatan pelatihan-pelatihan pengembangan profesi guru yang diselenggarakan oleh dinas pendidikan pusat termasuk pelatihan penggunaan TI untuk evaluasi PTK. Berdasarkan informasi yang diperoleh dari Depdiknas 2006. "Buku pedoman Pelaksanaan Bantuan Orpasional Sekolah", mengenai alokasi dana BOS untuk pengembangan profesi guru hanya mencapai $4 \%$. Begitu pula pada tahun anggaran 2016, dana untuk pembinaan dan pengembangan kompetensi guru tidak naik secara signifikan walaupun dana pendidikan kota Bandung berdasarkan APBD meningkat setiap tahun. Adapun Program pembinaan dan pengembangan 
kompetensi guru tersebut memiliki beberapa kegiatan antara lain disebutkan :

Program Peningkatan Mutu Pendidik dan Tenaga Kependidikan yang terdiri dari Pelaksanaan sertifikasi pendidik, Pelaksanaan uji kompetensi pendidik dan tenaga kependidikan, Pelatihan bagi pendidik untuk memenuhi standar kompetensi, Pembinaan kelompok kerja guru (KKG), Pembinaan lembaga penjamin mutu pendidikan (LPMP), Pembinaan pusat pendidikan dan pelatihan guru (PPPG), Pendidikan lanjutan bagi pendidik untuk memenuhi standar kualifikasi, Pengembangan mutu dan kualitas program pendidikan dan pelatihan bagi pendidik dan tenaga kependidikan.

Bantuan Operasional Sekolah (BOS) adalah langkah nyata pemerintah dalam rangka peningkatan akses masyarakat terhadap pendidikan dasar sekaligus sebagai upaya penuntasan target wajib belajar pendidikan dasar 9 tahun. Fakta yang sering terjadi adalah tuntutan kenaikan honor guru yang tidak dibarengi prestasi guru. Hal tersebut bertolak belakang dengan pengembangan profesi guru yang hanya dialokasikan sebesar $4 \%$. Pengembangan profesi guru ini sangat penting karena ada pelatihan-pelatihan khusus bagi guru untuk menunjang skills para guru tersebut. Tetapi dialokasikan lebih kecil daripada alokasi untuk honor guru. Anggaran dengan jumlah $4 \%$ tersebut, diutamakan untuk peningkatan kompetensi pembelajaran materi ajar. Sedangkan untuk peningkatan kemampuan guru dalam Penelitian Tindakan Kelas belum ada. Hal ini bertentangan, dibandingkan dengan manfaat yang diperoleh dari pengembangan kompetensi guru untuk bidang PTK. Guru yang telah mendapatkan pembekalan kompetensi yang tinggi baik dari materi pembelajaran maupun bidang PTK akan mengemas format pembelajarannya dalam bentuk yang menarik dan berkualitas disesuaikan dengan kemajuan TI. Melalui PTK ini, hasil pembelajaran guru dapat dievaluasi setiap waktu dan disesuaikan dengan kurikulum. Sehingga diharapkan dapat menghasilkan proses pembelajaran yang tepat dan akurat dengan informasi yang selalu up date.

Berdasarkan uraian di atas, permasalahan yang akan dipecahkan pada kesempatan pengabdian pada masyarakat ini yaitu;

(1) Bagaimanakah meningkatkan keterampilan guru-guru SMP dalam menggunakan software MS Excel dan SPSS dalam mengolah data Penelitian Tindakan Kelas.

3)Bagaimakah meningkatkan keterampilan guru-guru SMP dalam menganalisis secara statistika data Penelitian Tindakan Kelas beserta interpretasinya.

Politeknik Negeri Bandung (POLBAN) yang berada di jalur pendidikan vokasi dan atau terapan menjadi institusi yang tepat untuk ikut berperan dalam mengimplementasikan keilmuannya kepada masyarakat dari sisi Akademisi. Musyawarah Guru Mata Pelajaran (MGMP) Sekolah Menengah Pertama (SMP) adalah kelompok masyarakat yang berkiprah sama pada dunia pendidikan di tingkat Menengah. Dengan demikian, sangat tepat apabila intitusi dan kelompok tersebut bekerja sama dalam 
meningkatkan kualitas pendidikan Indonesia. Hal inilah yang menjadi latar belakang dilaksanakannya program pengabdian berbentuk pelatihan dengan judul : "Statistika untuk Pengolahan Data Hasil Penelitian Tindakan Kelas (PTK) Kelompok Musyawarah Guru Mata Pelajaran (MGMP) Di SMP Rayon Bandung Selatan “.

Lokasi yang dipilih adalah wilayah Kota Bandung Selatan tepatnya di kelompok Musyawarah Guru Mata Pelajaran (MGMP) SMP Rayon Bandung Selatan yang meliputi Kecamatan Astanaanyar, Bojongloa Kaler, Bojongloa Kidul, Regol, Babakan Ciparay dan Bandug Kulon. Jarak wilayah lokasi kegiatan dari kampus Polban berkisar (12-20) km ke arah Bandung selatan (peta terlampir). Tempat kegiatan pelatihan ditetapkan di SMP Negeri 43.

Alasan penentuan lokasi kegiatan pengabdian masyarakat adalah :

-Perbandingan jumlah guru MGMP yang telah mengikuti pelatihan atau pengembangan profesi guru di rayon Bandung Selatan sangat minim ( kirakira kurang dari 10\%).

-Cakupan wilayah SMP Rayon Bandung Selatan meliputi wilayah kecamatan pinggiran kota Bandung yang dinilai cukup strategis dan terjangkau dari segala arah .

\section{Tinjauan Teori}

Seorang guru profesional sebaiknya mengetahui secara mendalam tentang apa yang diajarkannya, mampu mengajarkan secara efektif, efisien, dan berkepribadian mantap. Menurut Syah dalam Sartika dkk (2012), memperinci kompetensi profesional guru ke dalam tiga aspek yaitu kompetensi kognitif (meliputi penguasaan terhadap pengetahuan kependidikan, pengetahuan materi bidang studi yang diajarkan, dan kemampuan mentransfer pengetahuan kepada siswa agar dapat berjalan secara efektif dan efisien), kompetensi afektif (sikap dan perasaan diri yang berkaitan dengan profesi keguruan), kompetensi psikomotorik (meliputi kecakapan fisik umum dan khusus seperti ekspresi verbal dan non verbal).

Teknologi yang digunakan dalam dunia pendidikan seperti komputer, kalkulator grafik, televisi dan lain sebagainya disebut dengan Information Computer and Tecnologi (ICT). Beberapa penelitian menunjukkan bahwa banyak guru yang semula kesulitan dalam melakukan penelitian dan mengolahnya dapat memperoleh hasil dengan waktu yang relatif singkat, lebih teliti dan akurat setelah menggunakan alat-alat ICT dibandingkan tanpa menggunakan ICT atau cara tradisional/konvensional. Menurut Peressini dan Knut (Jiang, 2006) terdapat 5 hal dasar mengapa teknologi dipilih untuk digunakan sebagai alat pedagogis dalam pembelajaran matematika, yaitu :

1. Teknologi dapat digunakan untuk management.

2. Teknologi dapat berperan sebagai alat komunikasi.

3. Teknologi dapat berperan sebagai alat evaluasi.

4. Teknologi dapat digunakan sebagai alat bantu memotivasi.

5. Pemanfaatan teknologi membantu pemahaman algoritma matematik siswa kepada arah yang lebih baik lagi, dapat meningkatkan keterampilan pemahaman konsep dan problem solving. 
Menurut Syah (1995) pada Laporan Pengabdian Masyarakat Nuryati dkk (2013), memperinci kompetensi profesional guru ke dalam tiga aspek, yaitu kompetensi kognitif (meliputi penguasaan terhadap pengetahuan kependidikan, pengetahuan materi bidang studi yang diajarkan, dan kemampuan mentransfer pengetahuan kepada siswa agar dapat berjalan secara efektif dan efisien), kompetensi afektif (sikap dan perasaan diri yang berkaitan dengan profesi keguruan), kompetensi psikomotorik (meliputi kecakapan fisik umum dan khusus seperti ekspresi verbal dan non verbal).

Berdasarkan beberapa pemahaman mengenai PTK dapat disimpulkan bahwa Penelitian Tindakan Kelas (PTK) adalah suatu pengamatan yang menerapkan tindakan di dalam kelas dengan menggunakan aturan sesuai dengan metodologi penelitian yang dilakukan dalam beberapa periode atau siklus. Berdasarkan jumlah dan sifat perilaku para anggotanya, PTK dapat berbentuk individual dan kalaboratif. Dalam PTK individual seorang guru melaksanakan PTK di kelasnya sendiri atau kelas orang lain, sedang dalam PTK kalaboratif beberapa orang guru secara sinergis melaksanakan PTK di kelas masingmasing dan diantara anggota melakukan kunjungan antar kelas. Karakteristik PTK adalah ; dilakukan oleh guru yang memahami bahwa proses pembelajaran perlu diperbaiki; refleksi diri, refleksi merupakan salah satu ciri khas PTK yang paling esensial ; Penelitian tindakan kelas dilaksanakan di dalam "kelas" sehingga interaksi antara siswa dengan guru dapat terfokuskan secara maksimal ; PTK bertujuan untuk memperbaiki proses pembelajaran secara terus menerus. PTK dilaksakan secara berkesinambungan di mana setiap siklus mencerminkan peningkatan atau perbaikan ; PTK merupakan salah satu indikator dalam peningkatan profesionalisme guru, karena PTK memberi motivasi kepada guru untuk berfikir Kritis dan sistematis, membiasakan guru untuk menulis, dan membuat catatan yang dapat ; PTK bersifat fleksibel sehingga mudah diadaptasikan dengan keadaan kelas ; PTK menggunakaan metode kontekstual.

Luaran program kegiatan pelatihan yang akan direncanakan ini berbentuk jasa yang akan ditunjukan dalam bentuk peningkatan keterampilan pengolahan data hasil Penelitian Tindakan Kelas PTK) bagi guru MGMP SMP Rayon Bandung Selatan di Jawa Barat. Sedangkan luaran yang berbentuk penghargaan diberikan kepada peserta yang telah mengikuti pelatihan ini dan mencapai kualifikasi yang ditentukan oleh penyelenggara yakni berbentuk sertifikat.

Manfaat kegiatan Pelatihan adalah, a.Bagi Mitra, meningkatkan kemampuan guru dalam penggunaan software komputer Ms Excel dan SPSS untuk mengolah data hasil PTK

a. Bagi Polban, meningkatkan peran dosen Statistika, Matematika, dan Fisika UP MKU Polban dalam pemberdayaan profesinya melalui kegiatan Pengabdian Masyarakat Dampak sosial dari kegiatan pelatihan dapat dirasakan antara lain :

a. Bagi pihak Polban, menjalin silaturahmi dengan masyarakat, khususnya para guru SMP di Rayon Bandung Selatan. Selain itu juga 
untuk lebih mengenalkan institusi Polban sebagai salah satu institusi pendidikan tinggi Negeri yang menyelenggarakan pendidikan pada jalur vokasi

b. Bagi Peserta Pelatihan, meningkatkan kemampuan guru dalam memanfaatkan sarana komputer khususnya software penggunaan microsoft excel dan aplikasi software SPSS (Statistical Package for Social Science) untuk pengolahan data hasil penelitian tindakan kelas (PTK).

\section{Metode}

Kegiatan pengabdian pada masyarakat dilakukan dalam bentuk pelatihan, didahului dengan penyampaian teori dilanjutkan dengan praktek penggunaan software komputer. Dengan pelatihan ini secara tidak langsung diharapkan dapat membantu meningkatkan kemampuan dalam pengolahan data hasil PTK. berupa peningkatan keterampilan dalam kegiatan ilmiah dibidang penelitian dengan memnfaatkan software komputer khususnya software penggunaan microsoft excel dan aplikasi SPSS (Statistical Package for Social Science) untuk pengolahan data hasil Penelitian Tindakan Kelas (PTK) .

Pelatihan direncanakan akan berlangsung selama 42 jam, dengan durasi selama tiga minggu, kegiatan dalam satu minggu berlangsung dua hari, yaitu direncanakan setiap Jumat dan Sabtu. Adapun jumlah peserta diperkirakan sekitar 20 - 25 orang meliputi MGMP dari beberapa SMP Rayon Bandung Selatan di Jawa Barat. Untuk lebih jelasnya, langkah-langkah rencana kegiatan pelatihan Pengabdian
Masyarakat digambarkan dalam diagram alir berikut :

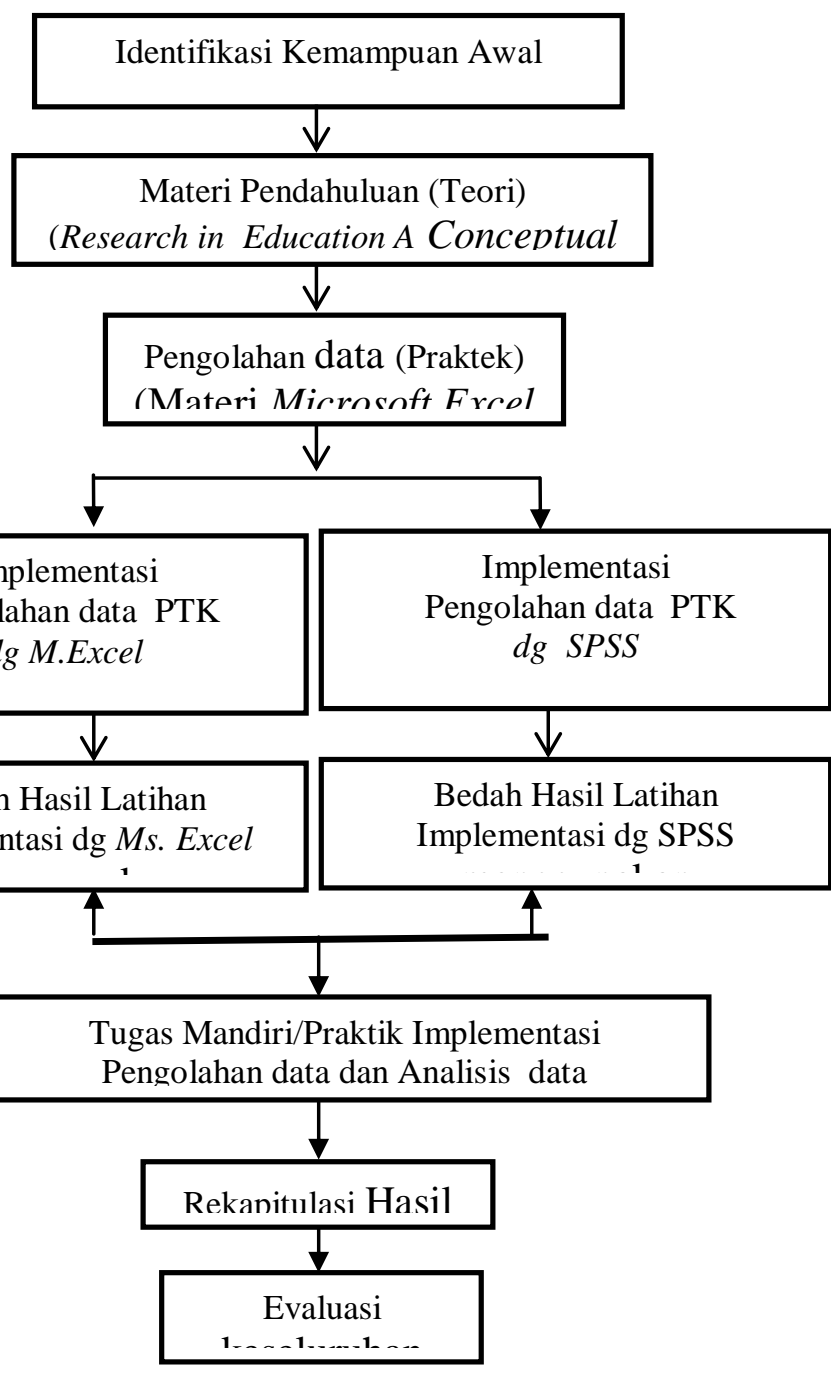

Gambar 2. Diagram Alir Rencana Kegiatan

Partipasi mitra berbentuk :

1. Melakukan komunikasi dan koordinasi dengan setiap perwakilan anggota MGMP di Rayon Bandung Selatan tentang pelaksanaan pelatihan.

2. Menyediakan tempat pelatihan berupa ruang kelas, ruang 
komputer dan sarana lain yang diperlukan dalam pelatihan.

\section{Hasil Dan Pembahasan}

Untuk menganalisis hasil keberhasilan pelatihan yang berupa perubahan kemampuan dan keterampilan terhadap materi yang dilatihkan didasarkan pada nilai hasil pretes dan Postes. Pretest diberikan kepada peserta pelatihan dengan materi uji yang disesuaikan dengan materi pelatihan, yakni Pendahuluan mengenai Penelitian Tindakan Kelas, Pengolahan data hasil Penelitian Tindakan Kelas dengan MS.Excel dan SPSS. Pretest diberikan kepada para peserta sebelum pelatihan dan Postest diberikan kepada peserta setelah pelatihan. Hasil pretest dan Postest diperoleh sebagai berikut, Tabel 1. Nilai Pretest Dan Postest Peserta Pelatihan

\begin{tabular}{|c|c|c|}
\hline Peserta & $\begin{array}{c}\text { Nilai } \\
\text { Pretest }\end{array}$ & $\begin{array}{c}\text { Nilai } \\
\text { Postest }\end{array}$ \\
\hline 1 & 16 & 19 \\
\hline 2 & 18 & 23 \\
\hline 3 & 23 & 24 \\
\hline 4 & 19 & 21 \\
\hline 5 & 20 & 21 \\
\hline 6 & 12 & 16 \\
\hline 7 & 14 & 20 \\
\hline 8 & 17 & 21 \\
\hline 9 & 18 & 19 \\
\hline 10 & 17 & 21 \\
\hline 11 & 18 & 23 \\
\hline 12 & 13 & 21 \\
\hline 13 & 16 & 20 \\
\hline 14 & 10 & 20 \\
\hline 15 & 19 & 23 \\
\hline 16 & 12 & 20 \\
\hline 17 & 14 & 21 \\
\hline
\end{tabular}

Tabel 2. Analisis Deskriptif Data

\begin{tabular}{|l|r|r|r|r|r|}
\multicolumn{1}{|c}{ Descriptive Statistics } \\
\hline & \multicolumn{1}{|c|}{ N } & Minimum & Maximum & Mean & Std. Deviation \\
\hline Pretest (Pengabdian) & 17 & 10.00 & 23.00 & 16.2353 & 3.36395 \\
Postest (Pengabdian) & 17 & 16.00 & 24.00 & 20.7647 & 1.88843 \\
Valid N (listwise) & 17 & & & & \\
\hline
\end{tabular}

Berdasarkan data dan hasil perhitungan statistik deskriptif dengan menggunakan SPSS 19.0, dapat diketahui nilai minimum sebesar 10; nilai maksimum sebesar 23; rata-rata sebesar 16,23 dan standar deviasi sebesar 3,36, dan kemampuan setelah pelatihan memiliki nilai minimum sebesar 16; nilai maksimum sebesar 24; rata-rata sebesar 10,76 dan standar deviasi sebesar 1,89. Terdapat kenaikan rata-rata nilai sebesar 27,02\% .

Berikut ini merupakan grafik data kemampuan sebelum pelatihan dan data kemampuan setelah pelatihan.

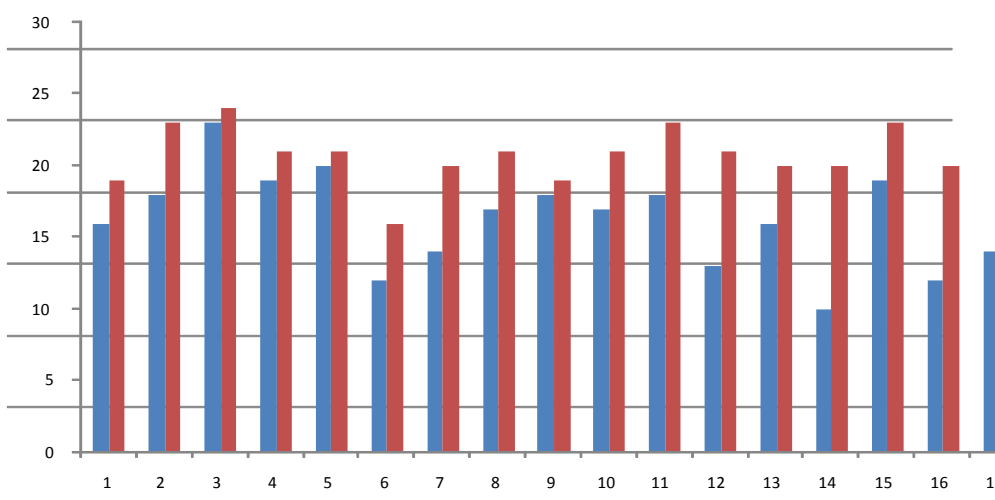

Gambar 3. Distribusi Data Kemampuan Peserta Sebelum dan Setelah Pelatihan

Analisis komparatif dipergunakan untuk mebandingkan kemampuan yang dimilki peserta sebelum dan sesudah pelatihan. Sebelum dilakukan uji perbandingan terlebih dahulu dilakukan uji normalitas dan homogenitas data. 


\section{Uji Normalitas Data}

Uji normalitas dilakukan dengan tujuan untuk mengetahui apakah data berdistribusi normal atau tidak. Jika data berdistribusi normal, maka uji komparatif dilakukan dengan menggunakan metode parametrik, yaitu paired t-test sedangkan jika data tidak berdistribusi normal maka uji komparatif dilakukan dengan metode non-parametrik yaitu uji Wilcoxon. Pengujian normalitas data dilakukan dengan menggunakan uji Shapiro-Wilk ( $\mathrm{n}<50)$. Berikut merupakan hasil pengujian normalitas data.

Tabel 3. Hasil Output Uji Kenormalan

\begin{tabular}{|l|r|r|r}
\hline & \multicolumn{3}{|c}{ Shapiro-Will } \\
\cline { 2 - 4 } & Statistic & \multicolumn{1}{c}{ df } & \multicolumn{1}{c}{ Sig. } \\
\hline Pretest (Pengabdian) & .974 & 17 & .886 \\
Postest (Pengabdian) & .916 & 17 & .128 \\
\hline
\end{tabular}

a. Lillief ors Significance Correction

Berdasarkan hasil pengujian normalitas diatas, diperoleh nilai $p$ value untuk data kemampuan sebelum pelatihan sebesar 0,886 dan nilai $p$ value untuk data kemampuan setelah pelatihan sebesar 0,128. Seluruh kelompok data memiliki nilai $p$-value lebih besar dari $\alpha=5 \%$ atau 0,05 ( $p$ value > 0,05), maka diketahui bahwa data kemampuan sebelum pelatihan dan data kemampuan setelah pelatihan berdistribusi normal.

\section{Uji Homogenitas Data}

Uji homogenitas dilakukan dengan tujuan untuk mengetahui apakah data homogen (memilik varian yang sama) atau tidak homogen (tidak memiliki varian yang sama. Untuk data sampel berpasangan, syarat uji homogenitas tidak mutlak, hal ini berarti jika kelompok data tidak homogen, metode yang digunakan dalam uji komparatif masih bisa dilakukan dengan menggunakan paired t-test. Hal ini dikarenakan, jika data sampel berpasangan asumsinya memiliki karakteristik yang sama sehingga data cenderung homogen. Namun, jika data sampel tidak berpasangan, syarat uji homogenitas mutlak, hal ini berarti jika kelompok data tidak homogen, metode yang digunakan dalam uji komparatif harus dilakukan dengan menggunakan uji alternatif yaitu uji Wilcoxon. Hal ini dikarenakan, jika data sampel tidak berpasangan asumsinya memiliki karakteristik yang tidak sama sehingga data cenderung heterogen.

Pengujian homogenitas data dilakukan dengan menggunakan uji Levene Statistics. Berikut merupakan hasil pengujian normalitas data.

Tabel 4. Hasil Output Uji Homogenitas

Test of Homogeneity of Variances

Pengabdian
\begin{tabular}{|r|r|r|r|}
\hline $\begin{array}{l}\text { Levene } \\
\text { Statistic }\end{array}$ & df 1 & \multicolumn{1}{c|}{ df 2} & \multicolumn{1}{c|}{ Sig. } \\
\hline 5.916 & 1 & 32 & .021 \\
\hline
\end{tabular}

Berdasarkan hasil pengujian normalitas diatas, diketahui bahwa nilai $p$-value yang diperoleh lebih kecil dari 0,021 ( $p$-value $<0,05$ ) yang berarti bahwa data kemampuan sebelum pelatihan dan data kemampuan setelah pelatihan tidak homogen, namun dikarenakan uji homogenitas bukan merupakan syarat yang mutlak dalam uji sampel berpasangan, maka pengujian selanjutnya akan dilakukan dengan uji komparatif paired t-test. 


\section{Paired t-test}

Paired t-test dilakukan untuk mengetahui apakah terdapat perbedaan antara dua kelompok data, dimana data yang digunakan tidak bebas (berpasangan) dan berdistribusi normal. Dalam penelitian ini akan dilakukan perbandingan antara data kemampuan sebelum pelatihan dan data kemampuan setelah pelatihan.

Pengujian hipotesis:

$\mathrm{H}_{0}$ : tidak terdapat perbedaan yang signifikan antara rata-rata kemampuan sebelum pelatihan dan kemampuan setelah pelatihan;

$\mathrm{H}_{1}$ : terdapat perbedaan yang signifikan antara rata-rata kemampuan sebelum pelatihan dan kemampuan setelah pelatihan.

$\alpha \quad: 5 \%$

Kriteria uji:

Tolak $\mathrm{H}_{0}$ jika $p$-value $<\alpha$

Terima $\mathrm{H}_{0}$ jika $p$-value $>\alpha$

Tabel 5. Hasil Output Paired t-test

\begin{tabular}{|c|c|c|c|c|c|}
\hline \multicolumn{6}{|c|}{ Paired Samples Statistics } \\
\hline & & Mean & $\mathrm{N}$ & Std. Deviation & $\begin{array}{c}\text { Std. Error } \\
\text { Mean }\end{array}$ \\
\hline \multirow{2}{*}{$\begin{array}{l}\text { Pair } \\
1\end{array}$} & Pretest (Pengabdian) & 16.2353 & 17 & 3.36395 & .81588 \\
\hline & Postest (Pengabdian) & 20.7647 & 17 & 1.88843 & .45801 \\
\hline
\end{tabular}

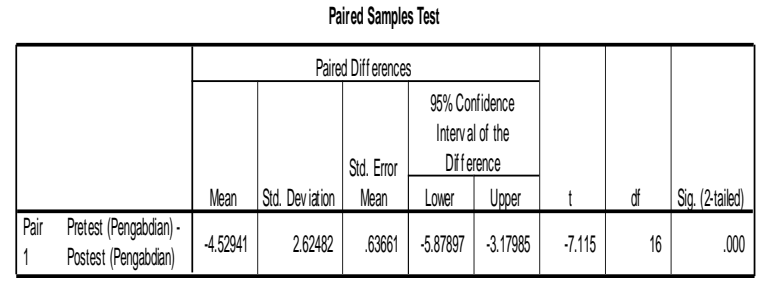

Berdasarkan hasil Paired t-test diatas, diperoleh nilai $p$-value lebih kecil dari 0,05 yaitu sebesar 0,000, yang menunjukkan terdapat perbedaan yang signifikan antara rata-rata kemampuan sebelum pelatihan dan kemampuan setelah pelatihan, dimana rata-rata kemampuan setelah pelatihan lebih sebesar 20,76 dan rata-rata kemampuan sebelum pelatihan hanya sebesar 16,23. Hal ini menunjukkan bahwa terdapat perubahan yang lebih bagus terhadap kemampuan setelah dilakukannya pelatihan.

\section{Analisis Pengolahan Data Kuesioner Hasil Pelatihan}

Evaluasi kegiatan secara keseluruhan dilakukan dengan pembagian kuesioner yang diisi para peserta. Jawaban dari peserta pelatihan dijadikan sebagai data kualitatif yang memberikan penguatan terhadap peningkatan kemampuan penggunaan software analisis data PTK. Kuesioner dijadikan bahan untuk menyimpulkan dan memberikan pertimbangan kebijakan dalam pelaksanakan pelatihan di masa yang akan datang.

Tabel 6. Rekapitulasi Jumlah Jawaban Kuesioner Dalam Persentasi

\begin{tabular}{|c|l|c|}
\hline No & \multicolumn{1}{|c|}{ Pernyataan } & $\begin{array}{c}\text { Sangat } \\
\text { setuju } \\
(\%)\end{array}$ \\
\hline 1 & $\begin{array}{l}\text { Proses administrasi untuk mengikuti pelatihan dengan ketentuan yang teratur dan } \\
\text { terbuka }\end{array}$ & 91,67 \\
\hline
\end{tabular}




\begin{tabular}{|c|c|c|}
\hline No & Pernyataan & $\begin{array}{l}\text { Sangat } \\
\text { setuju } \\
(\%)\end{array}$ \\
\hline 2 & $\begin{array}{l}\text { Jangka waktu pengadministrasian peserta mulai pendaftaran sampai dimulai } \\
\text { pelatihan cukup untuk melakukan penugasan dari SMK kepada guruyg } \\
\text { berkepentingan }\end{array}$ & 87,5 \\
\hline 3 & $\begin{array}{l}\text { Waktu pelaksanaan pelatihan yang telah diikuti bertepatan dengan tidak adanya } \\
\text { kegiatan kegiatan belajar mengajar (KBM) di SMK, hal ini } \\
\text { sangat afektif dan efisian }\end{array}$ & 100 \\
\hline 4 & Lingkungan dan suasanna tempat pelatihan sangat nyaman untuk belajar & 62,5 \\
\hline 5 & $\begin{array}{l}\text { Selama mengikuti pelatihan ini materi yang diikuti cukup menarik sesuai dengan } \\
\text { kebutuhan saya saat ini }\end{array}$ & 20,84 \\
\hline 6 & Materi pelatihan sangat banyak & 16,67 \\
\hline 7 & Materi pelatihan sulit diikuti dan dipahami & 25 \\
\hline 8 & $\begin{array}{l}\text { Penjelasan materi yang diberikan terlalu cepat sehingga saya sulit mengikutinya } \\
\text { mengikutinya }\end{array}$ & 0 \\
\hline 9 & $\begin{array}{l}\text { Waktu penyampaian materi terlalu singkat sehingga semua materi tidak selesai } \\
\text { dibahas }\end{array}$ & 33,33 \\
\hline 10 & Pemateri kurang menguasai materi sehingga kurang menarik & 0 \\
\hline 11 & $\begin{array}{l}\text { Pemateri kurang menguasai metodologi penyampaian sehingga suasana pelatihan } \\
\text { menjadi monoton }\end{array}$ & 0 \\
\hline 12 & $\begin{array}{l}\text { Bahan pelatihan yang dibagikan berbentuk modul-modul sangat menbantu dalam } \\
\text { memahami materi pelatihan }\end{array}$ & 83,33 \\
\hline 13 & $\begin{array}{l}\text { Isi naskah modul baik, sebab langkap berisi teori dasar, contoh } \\
\text { penerapan/guna, dan soal-soal pelatihan }\end{array}$ & 8,33 \\
\hline 14 & Sarana pelatihan (software) kurang memadai sehingga mengganggu kelancaran & 0 \\
\hline 15 & Pelaksanaan setiap mulai pelatihan tepat waktu & 91,67 \\
\hline 16 & Pelaksanaan pergantian dan pembahasan materi tepat waktu & 16,67 \\
\hline 17 & Jumlah peserta cukup, dibatasi sehingga suasana menjadi nyaman & 12,5 \\
\hline 18 & $\begin{array}{l}\text { Pelatihan yang serupa dapat dijadikan agenda MGMP tahunan yang } \\
\text { kesinambungan untuk masa yang akan datang. }\end{array}$ & 91,67 \\
\hline 19 & $\begin{array}{l}\text { Ruang pelatihan nyaman karena dipasilitasi denga instalasi jaringan pasok daya } \\
\text { listrik yang cukup, }\end{array}$ & 16,67 \\
\hline 20 & $\begin{array}{l}\text { Sistem kerja panitia sangat baik karena memiliki sistem yang terorganisir, } \\
\text { terstruktur, dan komunikatif, sehingga dapat dirasakan apresiasinya oleh perserta }\end{array}$ & 4,17 \\
\hline
\end{tabular}

\section{Kesimpulan Dan Saran}

Berdasarkan pembahasan pada bab sebelumnya, maka dapat diambil kesimpulan bahwa,

1. Pelatihan Pengolahan Data Penelitian Tindakan Kelas (SPSS dan MS.Exel) memberikan hasil yang sangat signifikan dalam meningkatkan pengetahuan maupun keterampilan para peserta pelatihan.

Terdapat perbedaan yang signifikan antara rata-rata kemampuan sebelum pelatihan dan kemampuan setelah pelatihan, dimana rata-rata kemampuan setelah pelatihan lebih sebesar 20,76 dan rata-rata kemampuan sebelum pelatihan hanya sebesar 16,23. Hal ini menunjukkan bahwa 
terdapat perubahan yang lebih bagus terhadap kemampuan setelah dilakukannya pelatihan.

2. Hasil jawaban kuesioner memberikan simpulan bahwa peserta menyatakan sangat antusias dan puas dalam mengikuti pelatihan, tanggapan peserta lainnya, administrasi pelatihan teratur, waktu pelatihan efisien dan afektif, materi sangat memuaskan, metoda dan modul sangat membantu dalam pelatihan, penyelenggara memiliki komitmen dan disiplin yang baik dalam melaksanakan pelatihan, telah terjalin kerjasama yang harmonis antara penyelenggara pelatihan dengan segenap jajaran yang menjadi mitra kerjasamanya. Disarankan perlu diadakan pelatihan olah data hasil penelitian-tindakan-tindakan kelas atau unit-unit kegiatan di SMP dengan menggunakan SPSS.

\section{DAFTAR PUSTAKA}

Anonim. 1999. Penelitian Tindakan Kelas. Jakarta: Dirjen Dikti

Depdiknas dan Depag. 2006. Buku pedoman Pelaksanaan Bantuan Orpasional Sekolah

Kusumah, Y. S. (2008). Konsep, Pengembangan, dan Implementasi Komputer-Based Learning Dalam Peningkatan Kemampuan High-Order Mathematical Thinking. Makalah disajikan dalam Pengukuhan Guru Besar Pendidikan Matematika FMIPA UPI Bandung.

Muldiani, R. Fenny (2011). Media Pembelajaran Berbasis Animasi Komputer pada Mata Kuliah Fisika Terapan untuk program Studi Teknik Aeronautika Politeknik Negeri Bandung, Jurnal Sigma-Mu Vol. 3 No. 1, UP MKU POLBAN, h. 11-20.

Nuryati, Neneng (2013) Pembelajaran Berbantuan Komputer Untuk Kelompok Musyawarah Guru
Mata Pelajaran (MGMP)

Matematika dan IPA Fisika SMP

Di Gugus 04 Kabupaten

Bandung Jawa Barat

Suhandini, Purwadi. 2003. Penelitian

Tindakan Kelas Geografi. Jakarta:

Direktorat PLP, Dikdasmen,

Depdiknas

Suharsimi, dkk. 2008. Penelitian Tindakan

Kelas. Jakarta. Bumi Aksara

Zainal Aqib, 2006. Penelitian

Tindakan Kelas Untuk Guru.

Bandung: Yrama Widya

Sartika, dkk, (2012), Pelatihan MS Office

danSoftware Winplot Bagi Guru

Matematika SMP Se Kota

Cimahi, Laporan Akhir Program

Pengabdian Pada Masyarakat,

Polban

Sudiapermana, Elih, (2014),

PENDIDIKAN, Disdik Siapkan

Guru Membuat Konten Ajar

Digital, Bandung, (Pikiran Rakyat), h-27

Suratmi. dkk, (2014), Peningkatan Keterampilan Penggunaan

Komputer Dalam Pembelajaran Untuk Kelompok Musyawarah Guru Mata Pelajaran (MGMP) Matematika, IPA \& Fisika Smk Se Kecamatan Lembang Kabupaten Bandung Barat Jawa Barat

Suyitno A, Suhitio. (2000). Pengembangan Rancangan Mata Kuliah Matematika Berbasis Kegiatan Eksperimen Pada Program Studi Pendidikan Matematika (Suatu Alternatif Model Pembelajaran). Proceding Seminar Nasional Pengembangan Pendidikan MIPA di Era Globalisasi .Univetsitas Negeri Yogyakarta, 22-8-2000.

Zulfaidahindriana.blogspot.co.id/2013/05/ pengertian-dan-karakteristik penelitian.html 